\title{
Teachers' Attitudes Toward Discovery Learning: A Case Study in Writing Class
}

\author{
Mala Rovikasari ${ }^{1}$, Suparno ${ }^{2}$, Slamet Supriyadi ${ }^{3}$
}

\begin{tabular}{l} 
ARTICLE INFO \\
\hline Article History: \\
Received 07.05.2019 \\
Received in revised form \\
08.02 .2020 \\
Accepted \\
Available online 01.03 .2020
\end{tabular}

\begin{abstract}
This research investigated teachers' attitudes and practices towards discovery learning, and also teachers' challenges in teaching writing. The method of this research used a case study. To collect the data, there were three ways, namely observation, interview, and documentation. The credibility data were checked through data triangulation and methodological triangulation. To analyze the collected data, it was used data reduction, data displays, and verification. The findings showed that teacher 1 and teacher 2 had a negative attitude in writing skill, but they had positive attitudes towards discovery learning in teaching writing. It was found that they enjoyed and liked using discovery learning. Additionally, their practices could transfer all activities to encourage students had a good writing. The challenges of using discovery learning in writing class were required much time and many classroom activities. Thus, the teachers played many roles in the process of writing.
\end{abstract}

(c) IJERE. All rights reserved

Keywords: ${ }^{1}$

Teacher's attitudes, discovery learning, writing

\section{INTRODUCTION}

Writing is one of four skills being the main concern for teachers. This skill has been included in the English subject in the Indonesian curriculum 2013. Nowadays, students are demanded to have good ability in communicating not only in oral but also in written. The activity of writing is related to generate ideas, arguments, opinions, using appropriate grammar, choice of vocabulary, revise and edit until becoming a good final written text. Moreover, writing is defined to express both thoughts of feelings and ideas poured into essays and surely people can understand (Darsono, Winarno, \& Slamet, 2018). Definitely, students need a teacher's guidance in the process of writing. The implementation of teaching writing using discovery learning become a challenge for teachers, especially for foreign teachers. Since the government suggested discovery learning as one of methods which should be applied in teaching and learning process based on the Indonesian Minister of Education and Culture's Regulation No. 22, 2016 on Process Standard of Basic and Secondary School. In this case, the researcher found that teachers choose and use discovery learning in teaching writing.

The definition of discovery learning is a teaching method in which a teacher guides students to discuss and ask questions and reach information by themselves, so they can discover and find out solutions through practices (Balim, 2009). Besides that, discovery learning requires discovery mental processes including observing, measuring, classifying, suspect, explaining, and making decisions (Efrini, 2016). Discovery learning is a potential method to improve classes' instruction, strategy and students' achievement where the memorization of definitions is not enough in reaching a goal of learning (Bicknell-holmes \& Hoffman, 2000). Additionally, there are six stages in discovery learning, namely stimulation, problem statement, data collection, data processing, verification, and generalization (Rahmi \& Ratmanida, 2014).

The role of the teacher can play important for learning the writing process. Moreover, the role refers to the part that a teacher can play in carrying out learning tasks as well as the relationship with students (Nunan \& Carter, 2001). In teaching writing, a teacher can be a facilitator, demonstrator, responder, evaluator, and motivator. Thus, the attitudes of a teacher about the method can affect the process of

\footnotetext{
corresponding e-mail: ${ }^{1}$ malarovikasari@gmail.com orcid.org/0000-0002-4625-8010

2drs.suparno@rocketmail.com. orcid.org/0000-0002-4116-2562

${ }^{3}$ pripus.lppmuns@yahoo.co.id orcid.org/0000-0002-2148-5305

Corresponding e-mail: malarovikasari@gmail.com

1,2,3Sebelas Maret University
} 
teaching. Here, a teacher can/can't like teaching writing using discovery learning. As a result, it can value and determine for classroom activities, instruction, strategy in which the teacher used. The definition of attitudes is "an internal belief that influences actions" (Schunk, 2012). Based on Dart et al. (1998), teacher's attitudes gives a impact directly to classroom practices and teaching pedagogy (Malloy, 2016). Based on Weden (1991), many researchers think that attitudes include cognitive, affective, and behavioral component (Darwish, 2016). The cognitive component includes 'beliefs or perceptions about the objects or situations related to the attitude'. Then, the affective component is related to the 'feelings or and emotions towards an object about like or dislike and with or against'. The last is about the behavioral component which means that the attitudes can encourage and provoke someone to adopt the particular behaviors.

Research on the attitudes has found that the positive attitudes bring teachers are successful in meeting between writing and its objectives to their students. Certainly, it is supported by teachers' understanding of their roles in developing classroom writing (Giles \& Kent, 2015). Moreover, discovery learning had some advantages towards students, namely it made students to understand the material easily and increase students' motivation (Krisnawati, 2015). Then, the attitudes towards the use of discovery learning in writing namely, stimulation, problem statement, data collection, verification, generalization is positives, except data processing stage. In this stage, the teacher had limited time. Then, for teacher's practices included giving the comments to students' works, making students pay attention, and giving a motivational correction (Mushtoza, 2016). Based on the phenomena above, this research investigated three main aspects, namely teacher's attitudes, teacher's practices, and teacher's challenges towards discovery learning in teaching writing.

\section{METHOD}

The research used a case study to investigate teacher's attitudes and practices toward discovery learning in writing class. The definition of a case study is a depth exploration of the bounded systems such as an activity, event, process, individual, groups based on extensive data collection (Creswell, 2012). The participant of the research were two writing teachers. The first participant is a male teacher who is 54 years old. Then, the second participant is a female teacher who is 48 years old. Teacher 1 and Teacher 2 have been teaching writing skill in Vocational School 2 in Indonesia. There were three sources of data in this research including: the participants who was the main of source, events that happened in teaching-learning process of writing skill, and documents which included lesson plans, textbooks, syllabus, etc. In collecting the data, the researcher used semi-structured interview, observation, and documentation. In the first technique, the researcher asked some questions to the teachers whereas they answered those questions openly and freely from their own perspectives about discovery learning in teaching writing skill. Secondly, the observation is needed because it provides a description of phenomena completely which is occurring and there is an independent of the subject study (Gall, Gall, \& Borg, 2003). Here, the events or phenomena occurring in the writing class was observed by the researcher to know and investigate teacher's practice and attitudes directly. In conducting the observation, the research did not involve in the activities of the subject of the study. Thirdly, 'the documentation or is a research method applied to written or visual materials or the purpose of identifying specified characteristics of the materials' (Ary, Jacobs, Sorensen, \& Razavieh, 2010). After the data were collected, the researcher used triangulation in ensuring the credibility. Triangulation is defined as confirming the results which are based on the information from many sources (Hancock \& Algozzine, 2006). This researcher used data triangulation and methodological triangulation. Besides that, the collected of data were analyzed by using Flow Model Analysis in which consisted of three actions, namely data reduction, data displays, and drawing conclusion/verification (Miles, Huberman, \& Saldana, 2014).

\section{RESULTS}

\section{Teacher's Attitudes towards Discovery Learning in Teaching Writing}

The results of interview revealed several findings. First core is about teacher's attitudes towards writing skill. Teacher 1 states that writing is one of important skill that he must master as a writing teacher. On the other hand, he says, "I am not quite good enough in writing and the hardest step in writing is planning step". In this step, teacher 1 says that he has a difficulty to find and determine the ideas which will be written. While teacher 2 was being a student until now, writing is a big challenge for her. He says, "Writing is very useful for 
his life such as writing e-mail, job application but it's quite difficult to write especially in collecting ideas." She does not like collecting ideas because it will spend more time and energy to think and develop ideas in the paragraph. Meanwhile, teacher 2 emphasizes that she always tries to learn how to result a good writing as native's writing.

The second core is about teaching writing using discovery learning. Teaching writing using discovery learning is challenging for teacher 1 . Discovery learning can make his students to be creative and independent. He says, "It's challenging because it can make students creative, independent, easier remember material". Besides that, the students enjoy each stages which can help and build them in remembering and thinking. In addition, teacher 1 are satisfied when he can find out and see the result of student's writing based on core competence and basic competence that is taught. Also, the student's final writing is appropriate with social function, language feature, coherent and cohesion of the kind of text. Furthermore, teacher 2 says, "Discovery learning is enjoyable and helpful". She also says that the curriculum of 2013 emphasizes students to be active and a teacher does not always explain during the lesson. Hereby, the students are trained to discover the material by themselves with a teacher's guidance. Besides that, the stages of discovery learning has a clear purpose to help students' learning writing process. So, teacher 2 can enjoy every process that happens to them.

The third core is about the stages of discovery learning. Based on the interview result, teacher 1 and teacher 2 agree that they like all stages of discovery learning to teach writing skill. Then, they mention that their favorite stage is generalization stage. In the generalization, they only listen and see how to students conclude material attentively. The last core is about a teacher's confident. Teacher 1 says that he is confident when teaching writing using discovery learning. In a fact, he have prepared and arranged the lesson plans well. Besides that, he tells that he always provides authentic of texts when he is teaching writing as his responsibility as a writing teacher. It is supported by teacher 2 too. She collects and uses many books to support the teaching and learning writing process. Besides that, teacher 1 and teacher also reveal their fears in using discovery learning, namely time management and classroom activities.

\section{Teacher's Practices in Teaching Writing Using Discovery Learning}

Based on the observation, the researcher found that the teachers started the lesson by praying together and checking students' attendance. As mentioned before, there are six stages in discovery learning including stimulation, problem statement, data collection, data processing, verification, and generalization. For the material, the first teacher discussed an application letter and the second teacher discussed a factual report.

The first stage is stimulation. For teacher 1, he provided the example of application letter then guided students with the questions such as 'what do you think about this text, and why do people write this text?'. Thus, the students observed the application letter and they gave their opinions about this text. Meanwhile, teacher 2 gave the report texts included the picture of elephant and whale then asked students to observe it and explain their information obtained. The second stage is problem statement. The researcher found that both teachers guided their students to ask questions related to social function, generic structure, language feature, and the detail information of the texts. Hereby, they encouraged the students to make questions in understanding those texts. The third stage is data collection. In this stage, teacher 1 and teacher 2 divided their students into 6-7 groups in which each group concluded 5-6 persons because this school had the large classes. In teacher 1's class, the students were asked to read the text and also read the textbook related to the application letter and find the information about the text and its part with their groups. Besides that, the instruction used by teacher 1 was almost the same as teacher 2. Teacher 2 also asked students to read and discuss the factual reports in the textbook in groups. The researcher found that the students are able to find the information through their textbooks and discussions.

The fourth stage is data processing. In this stage, the students with their groups listed and wrote down the information about the purpose of the text, generic structure, language features (a tense used) from the text. The fifth stage is verification. Hereby, the teachers gave a feedback about their works. So, in this stage students knew that whether their works were correct or incorrect. The last stage is generalization. In both teachers' classes, all students could conclude what they have learned (application letter and factual report). They explained the social function of text, generic structure, and language feature. After that, the teachers 
asked to go back their own seats. They asked students to write a text related to the topic. The researcher found that teacher 1 motivate students to have ideas that application letters can be addressed for schools, companies, etc. Also, for the writing class of teacher 2, it was found that she divided the different topics each student in writing a factual report. For instance, student A got 'A car' as his topic, student B got 'An Earthquake' as her topic, etc. Before the students submitted their final writing, teacher 2 was so active to go around their students to make sure whether the students had difficulties or not. Also, it was found that she responded students' writing by showing their mistakes and asking them to correct them. On the other hand, after teacher 1 helped in deciding the topic, the researcher found that he only sat on his chair. He asked the students if there were difficulties, they could move forward to ask him. As a result, most students did not ask him about their problems. It can be concluded that teacher 2 plays multiple roles as a demonstrator, motivator, responder, and evaluator. Meanwhile, there was a missing role from teacher 1, namely as a responder. After finishing writing, the students submitted their works to the teachers. Then, they evaluated them by using five indicators, namely content, organization, vocabulary, syntax, and mechanic.

\section{The Challenges of Teaching Writing using Discovery Learning}

There are several challenges or problems when the teachers used discovery learning in teaching writing. First, discovery learning consists of many stages. Based on both teachers, there are many activities that should be prepared and conducted. As a result, it was linked to acquiring much time. They explained that in the data collection and data processing needed more time. The researcher found that the data collection and data processing in which there were many activities including collecting the information about the texts from textbook and material provided teachers in a piece of paper. It started from writing down the purpose of text, identifying generic structure, language features, and content of the text. Then, there was a discussion between the teachers and students when they had difficulties. Consequently, teacher 2 needed additional meeting for discussing one topic. Second, in the stage problem statement, it was found that there were some students passively in both teachers' writing classes. But, the teachers guided students to make questions such as, 'why does the writer write this text?'. This step is really helpful for students in discovering the concepts by themselves without the teachers' explanation directly. Besides that, there were several students who were confused when teacher 1 asked to identify the text (e.g. generic structure) in groups. Then, it is found that the students sometimes chatted with their friends which was not related to the topic.

\section{DISCUSSION AND CONCLUSION}

Based on the findings above, it showed that teachers' attitudes towards writing skill are negative. The teachers had negative experience when they were students. They viewed that the most difficult in the steps of writing was planning in which it needed knowledge and kept reading to get and determine what they would write about (ideas). Additionally, they disliked collecting the ideas that needed more energy and time. This result was viewed by the teachers as a writer.

Furthermore, teachers' attitudes towards writing skill do not affect their attitudes in teaching writing. It was found that the teachers' attitudes towards the use of discovery learning in teaching writing were positive. The term of teachers' attitudes related to enjoy, like, and confidence. As mentioned in the previous study, the attitudes can be linked to 'confidence, responsibility, caring, discipline', etc. (Hanafi, 2016). In this research, teachers acknowledged that they enjoyed teaching writing using discovery learning. It was indicated that the writing teachers have understood the principle and stages of discovery learning. Then, they showed their confidents in teaching writing using discovery learning as teaching method. They also felt that discovery learning is very beneficial for their students in building students' motivation and making students to enjoy in learning writing. They really knew about what they should do to encourage students in writing class. For instance, by giving the texts and picture, it could stimulate students in learning writing before they asked them to write. Consequently, it is good for students because it can make students enjoy in learning without imaging the difficulty of writing process. Hereby, students are helped to understand a text starting knowing genre of texts and parts of text including social function, generic structure, and language feature. So, they are able to find their concepts before they start to write. Moreover, they liked all stages in discovery learning. They mentioned that the easiest stage was generalization stage. In this stage, they only listened to their students explained the conclusion of the topic that had been discussed. Also, they could add 
the information for students' explanation. Afterwards they tried to teach professionally. As stated in the previous study, in the reflective of teacher's attitudes, teachers concern on students' successes and take responsibilities in teaching writing, and it shows that the extent of teachers' understanding about writing skill (Street, 2003). Thus, the writing teachers were confident in teaching writing using discovery learning. It reflected how they have prepared the writing material in their lesson plans. Also, they used and adopted many books to complete material for each other. The great effort as a writing teacher is giving authentic texts to their students. I

According to teachers' practices, they had transferred the subject matter (writing) successfully to students. They conducted all stages based on the regulation, namely: (1) stimulation: teachers stimulated their students by giving the texts and picture; (2) problem statements: students asked questions guiding teachers about social function, generic structure, language feature, the other information of the text; (3) data collection: students collected the information about the text and its social function, generic structure, language feature by reading the textbooks, discussing in groups; (4) data processing: students tried to write down what they have got from data collection stage; (5) verification: students presented their works and teachers gave a feedback; and (6) generalization: students made a conclusion about the topic or material that had been discussed. This result is supported by the previous study that teacher's practices in using discovery learning in teaching writing showed that there were six roles of discovery learning that implemented by the teacher, such as pre-teaching, depending on the class, distributing copies of the task, addressing the necessary vocabulary, providing students time to work and producing the final copy (Krisnawati, 2015). In teaching writing, the verification stage (Tante, 2018). Besides that, teacher 2 played many roles in teaching writing such as a demonstrator, motivator, responder, and evaluator. For teacher 1, he played many roles except for as a responder.

The challenges or problems in which the writing teachers had lack of time in doing many activities. Actually, discovery learning would require much time in learning (Rahmi \& Ratmanida, 2014). As the researcher mentioned before, teachers felt that there were many activities in using discovery learning. Sometimes, they needed additional time or meeting to make sure that students' had good writing. Consequently, they have tried to manage time well. What they planned in the lesson plan, they could do it all. Thus, there were some students confused to identify the generic structure of the text.

Based on the findings and discussion above, it can be concluded that teacher 1 and teacher 2 are positives to six stages in discovery learning including stimulation, problem statement, data collection, data processing, verification, and generalization. In addition, they should encourage their performances in data collection and data processing stage in which management time is needed to build the effective classes.

\section{REFERENCES}

Ary, D., Jacobs, L. C., Sorensen, C., \& Razavieh, A. (2010). Introduction to reseacrh in education. USA: Wadsworth Cengange Learning.

Balim, A. G. (2009). The effects of discovery learning on students' success and inquiry learning skills. Eurasian Journal of Educational Research Egitim Arastirmalari-Eurasian Journal of Educational Research, 35(35), 1-20. https://doi.org/10.6084/m9.figshare.3437033

Bicknell-holmes, T., \& Hoffman, P. S. (2000). Experience, explore : Discovery learning in library instruction. Reference Services Review, 28(4), 313-322. https://doi.org/10.1108/00907320010359632

Creswell, J. . (2012). Educational research: Planning, conducting, and evaluating quantitative and qualitative research (4th ed.). Boston: Pearson.

Darsono, D., Winarno, W., \& Slamet, S. Y. (2018). The need textbook writing of children's story based on character education. International Journal of Educational Research Review, 3(2), 1-8. https://doi.org/10.24331/ijere.391780

Darwish, H. (2016). Teachers' attitudes and techniques towards efl writing in egyptian secondary schools. International Journal for 21st Century Education, 3(1), 37-57.

Efrini, M. (2016). Approach in curriculum 2013 in teaching English. 1(2), 93-102.

Gall, M. D., Gall, J. P., \& Borg, W. R. (2003). Educational research: An introduction (7th ed.). USA: Pearson Education. 
Giles, R. ., \& Kent, A. . (2015). An investigation of elementary preservice teachers' attitudes towards writing. TOJNED, 5(3), 14-22.

Hanafi, H. (2016). The effect of discovery learning method application on increasing students' listening outcome and social attitude. Dinamika Ilmu, 16(2), 291. https://doi.org/10.21093/di.v16i2.552

Hancock, D. R., \& Algozzine, B. (2006). Doing case study research. In Dalton Transactions. https://doi.org/10.1039/c8dt02254b

Krisnawati, E. L. I. (2015). The implementation of teaching writing using discovery learning to the eighth grade students at smpn 1 grogol in academic year 2014/2015. University of Nusantara PGRI Kediri.

Malloy, G. D. (2016). How preservice teachers' attitudes and beliefs about writing inform their view of writing instruction: A case study. Montana State University.

Miles, M. B., Huberman, A. M., \& Saldana, J. (2014). Qualitative data analysis: A methods sourcebook. USA: SAGE Publications.

Mushtoza, D. A. (2016). Discovery learning in teaching report writing for junior high school students based on 2013 curriculum. IJET, 5(1), 55-77.

Nunan, D., \& Carter, R. (2001). The Cambridge guide to teaching english to speakers of other languages. London: Cambridge University Press.

Rahmi, Y., \& Ratmanida. (2014). The use of discovery learning srategy in teaching reading report texts to senior high school students. JELT, 3(September), 179-188.

Republic of Indonesia. 2016. The Indonesian minister of education and culture's regulation No. 22, 2016 on Process Standard of Basic and Secondary School. Jakarta.

Schunk, D. . (2012). Learning theories: An educational perspectives (6th ed.). Boston: Pearson.

Street, C. (2003). Pre-service teachers ' attitudes about writing and learning to teach writing : Implications for teacher educators. Teacher Education Quarterly, (Summer), 33-50. https://doi.org/https://pdfs.semanticscholar.org/2422/57ed7ab0068e759507ff3ee2d7e6a541f7b5.pdf

Tante, A. C. (2018). Primary school teachers' classroom-based assessment feedback culture in English language. International Journal of Educational Research Review, 3(4), 32-47. https://doi.org/10.24331/ijere.425151 